\title{
Architecture in Institutional Management Systems using Odoo Enterprise Resource Planning at UIN Maulanạ Malik Ibrälimi Malang
}

Supriyono

\author{
Department of Informatics, Faculty of Science and Technology \\ Universitas Islam Negeri (UIN) Maulana Malik Ibrahim, Malang, Indonesia
}

priyono@ti.uin-malang.ac.id

\begin{abstract}
Rapidly evolving information systems and technology have compelled organizations, particularly educational institutions, to adapt their institutional evolution. The researcher's goal is to build an Odoo ERP-based institutional management system architecture at UIN Maulana Malik Ibrahim Malang in order to gain a competitive advantage in realizing the university's vision, mission, and goals, as well as in the future implementation phase of the recommended application portfolio. Information systems strategic planning is a significant transformation for a company, and it is based on user needs that are aligned with business strategy. The impact and alignment categories are used to categorize the information systems strategic planning technique. The impact category methodology is useful for creating and justifying the use of new information technologies. While the alignment methodology (alignment) serves to align the objectives of the information system with the goals of the organization. The Star UML was used to design the system architecture.
\end{abstract}

Keywords: Odoo ERP; Impact; Alignment; UML

\section{Introduction}

An information system is a crucial instrument for achieving corporate objectives. Every business must carefully define information needs and examine the vision, goal, and functions carried out, as well as who executes them and what data and information are required to carry out the many functions and processes most important to the information structure [1]. Without a structured plan for the growth of information systems, the organization will lack a priority scale and appear uneven [2]. Without a structured plan for the growth of information systems, the organization will lack a priority scale and appear uneven [3].The risks involved with making decisions concerning information systems and information technology can almost certainly be decreased if a university or higher education institution has a sound strategic plan. However, many colleges and higher education institutions overlook this and disregard strategic planning as a non-essential component [4]. Implementing information systems and information technology in an organization, including educational institutions, has three main goals: (1) increasing work efficiency by automating various information management processes, (2) increasing management effectiveness by satisfying decision makers' information needs, and (3) improving competitiveness or increasing the university's competitive advantage by changing the style and way of conducting its main business. If there is a guarantee of alignment between the information systems strategy and information technology with the organization's business plan, the three goals can be met to their full potential.

Islamic State University of Maulana Malik Ibrahim Malang (UIN Malang) is one of Indonesia's largest Islamic universities. The Center for Information Technology and Databases is responsible for the operation and management of information technology at 


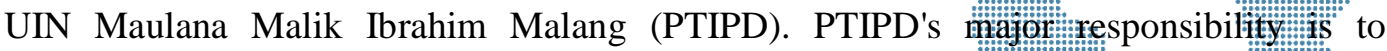

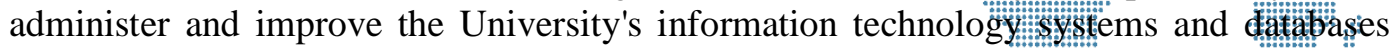
(Ortaker, Article 80). According to the results of a user satisfaction survey (2021) University's administration and development of information systems and information technology, $90 \%$ of respondents felt that the development of information systems and information technology was not directed and unplanned. The argument is that the development of information systems and information technology has failed to meet needs and has failed to consider the university's future business procedures.

By paying attention to the problems that UIN Maulana Malik Ibrahim Malang is facing, it is impossible to deny that good and strategic planning of information systems and information technology can serve as a guide in developing information systems and information technology in the future to achieve the university's goals, namely the realization of superior Islamic higher education and international reputation. As a result, research at UIN Maulana Malik Ibrahim Malang on strategic planning of information systems and information technology has a place and is necessary. Several universities in Indonesia have adopted research-based information systems. The Strategic Management of Information Technology (SMIT) established by Flodstrom is based on related research [5]. The strategic design for adopting information technology is done in conjunction with the business plan and takes into account the strategic environment. However, features of institutional development based on Odoo Enterprise Resource Planning were not included in this development research (ERP). Odoo ERP is a multi-platform information system development framework [6]. Its design offers for a great deal of versatility when it comes to integrating with other apps. Similarly, Odoo ERP provides a high level of security to make it easy for users to store data virtually.

This study analyzes developing strategic plans based on the state of information systems and information technology at the time the research was conducted, in order to align them with the university's development path. The talk will center on information systems and technology planning for business processes associated to the Tri Dharma of Higher Education. This study's ultimate product is a blueprint for information systems and information technology strategic planning.

\section{Research Methodology}

The data collection method used is a combination of survey and case study approaches. Analysis of strategic planning documents was carried out to investigate the influence of strategic planning on policy and regulation of management and information strategies. The sample of this research is academic staff in Indonesia who are studying in Australia. Twenty-six respondents were system users, not information providers or system administrators.

Research questions [7] using a questionnaire method with the Likert Scale method. Questionnaire method to determine the perception of what an information system is, how it functions in the institution, and to investigate the perceived usefulness. The technique of testing the questionnaire sample aims to clarify the ambiguity of the questionnaire. Data processing is carried out based on findings from document analysis. Data processing uses the Mann-Whitney Test (U test) statistical method, and Spearman Rank Order Correlation Test (Rho test), and content analysis [7].

\subsection{Information Systems (IS) and Information Technology (IT) Strategy}

The process of making IS/IT strategy should not only focus on technology analysis. The most effective way that can be taken is to analyze existing business problems, changes in the environment, and realize that IS/IT is only one of the solutions offered. Earl also suggested that the IS strategy concentrate on identifying the information systems needs of the organization. While the IT strategy concentrates on identifying information technology needs and supporting infrastructure [8]. 
To determine the IS/IT strategy that can support the achievenerent of the organimation's vision and mission, it is necessary to understand the organization understanding includes an explanation of the following: why a business is run, where is the goal and direction of the business, when the goal is achieved, 费w to achieve the goal and are there any changes that must be made. So in building an IS/FT strategy, the central issue is the alignment (alignment) of the IS/IT strategy with the organization's business strategy.

\subsection{Information Systems and Information Technology Strategic Planning Methodology}

Information systems strategic planning methodology is grouped into two categories, namely impact and alignment [9]. The impact category methodology is useful for creating and justifying the use of new information technologies. While the alignment methodology (alignment) serves to align the goals of information systems with organizational goals.

\subsubsection{Analysis of Critical Success Factors}

Analysis of Critical Success Factors (CSFs) can have a good impact on methodological alignment. CSFs in the context of strategic information systems planning are used to clearly interpret objectives, tactics, and operational activities in terms of key information needs of managers and the strengths and weaknesses of existing organizational systems. CSFs can be defined if organizational objectives have been identified. The goal of CSFs is to interpret the objectives more clearly to determine what activities should be performed and what information is needed. The role of CSFs in strategic planning is as a liaison between the organization's business strategy and its information system strategy, focusing the information system strategic planning process on strategic areas, prioritizing proposed information system applications and evaluating information system strategies.

\subsubsection{Analysis of Critical Success Factors}

Value chain analysis (value chain) was proposed by Michael Porter in 1984. According to Porter, every company is a collection of activities carried out for production, marketing, delivery and support of products. All of these activities can be represented using a value chain. Porter also explains that information technology is one of the main supporters of the value chain.

\section{Results and Discussion}

\subsection{Business Process Mapping Results}

Table 1. Level 1 Sub-Satker Business Process (Sub-Process)

\begin{tabular}{|c|l|c|l|}
\hline $\begin{array}{c}\text { Code } \\
\text { Subsatker }\end{array}$ & Subsatker & $\begin{array}{c}\text { Sub- } \\
\text { Process } \\
\text { Code }\end{array}$ & \\
\hline 1 & Faculty & 1.1 & Carry out education and teaching \\
\hline & & 1.2 & Carry out research and development of science and technology \\
\hline & & 1.3 & Carry out community service \\
\hline & & 1.4 & Carrying out the development of the academic community \\
\hline & & 1.5 & $\begin{array}{l}\text { Carry out general administration, academic, student affairs, planning, } \\
\text { finance and reporting services }\end{array}$ \\
\hline & $\begin{array}{l}\text { Postgradu } \\
\text { ate }\end{array}$ & 2.1 & Carry out education and teaching \\
\hline & & & Carry out research and development of science and technology \\
\hline & & 2.2 & Carry out research and development of science and technology \\
\hline & & 2.3 & Carry out community service \\
\hline & & 2.4 & Carrying out the development of the academic community \\
\hline & Generry out general administration services, academic, student affairs, \\
planning, finance and reporting
\end{tabular}




\begin{tabular}{|l|l|l|l|} 
& $\begin{array}{l}\text { Section } \\
4\end{array}$ & 4.2 & Conduct program evaluations, budgets, and performance reporting \\
\hline 5 & $\begin{array}{l}\text { Financial } \\
\text { departmen } \\
\mathrm{t}\end{array}$ & 5.1 & Execute budget and treasury \\
\hline
\end{tabular}

\begin{tabular}{|l|l|l|}
\hline & 5.2 & Perform budget verification, agency accounting, SIMAK SMN, BLU
\end{tabular}

\begin{tabular}{|l|l|l|l|}
\hline 6 & $\begin{array}{l}\text { OKH } \\
\text { Bagian } \\
\text { section }\end{array}$ & 6.1 & Manage, develop, and transfer employees \\
\hline
\end{tabular}

\begin{tabular}{|l|c|c|l|}
\hline & section & 6.2 & $\begin{array}{l}\text { Carry out organizational and management arrangements, } \\
\text { performance reports, and laws and regulations }\end{array}$ \\
\hline 7 & $\begin{array}{l}\text { Academic } \\
\text { Section }\end{array}$ & 7.1 & Manage academic information \\
\hline & & 7.2 & Carry out academic administration \\
\hline
\end{tabular}

\begin{tabular}{|c|l|l|l|}
\hline & & 7.2 & Carry out academic administration \\
\hline 8 & $\begin{array}{l}\text { Student } \\
\text { Affairs } \\
\text { Bagian }\end{array}$ & 8.3 & Performing academic services \\
\hline & & $\begin{array}{l}\text { Carrying out student administration, fostering student talents and } \\
\text { interests }\end{array}$ \\
\hline
\end{tabular}

\begin{tabular}{|c|c|c|c|}
\hline & Bagian & 8.2 & Carry out administration and empowerment of alumni \\
\hline 9 & $\begin{array}{l}\text { Cooperati } \\
\text { on Section }\end{array}$ & 9.1 & $\begin{array}{l}\text { Carry out administrative preparation, cooperation, and institutional } \\
\text { development }\end{array}$ \\
\hline
\end{tabular}

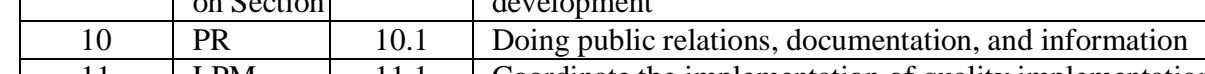

\begin{tabular}{|l|l|c|l|}
\hline 10 & PR & 10.1 & Doing public relations, documentation, and information \\
\hline 11 & LPM & 11.1 & $\begin{array}{l}\text { Coordinate the implementation of quality implementation of } \\
\text { academic activities at the Faculty and Postgraduate levels }\end{array}$ \\
\hline & & 11.2 & $\begin{array}{l}\text { Controlling and auditing the quality implementation of academic } \\
\text { activities at the Faculty and Postgraduate levels }\end{array}$ \\
\hline
\end{tabular}

\begin{tabular}{|c|c|c|c|}
\hline & & 11.2 & $\begin{array}{l}\text { Controlling and auditing the quality implementation of academic } \\
\text { activities at the Faculty and Postgraduate levels }\end{array}$ \\
\hline & & 11.3 & $\begin{array}{l}\text { Implementing the quality of student development and mentoring } \\
\text { (Quality Mentoring and Development Center Student) }\end{array}$ \\
\hline 12 & LP2M & 12.1 & $\begin{array}{l}\text { Carry out the preparation of plans, evaluation of programs and } \\
\text { budgets as well as reporting for research }\end{array}$ \\
\hline
\end{tabular}

\begin{tabular}{|l|c|l|}
\hline & 12.2 & $\begin{array}{l}\text { budgets as well as reporting for research } \\
\text { budgets as well as reporting for community service }\end{array}$ \\
\hline & 12.3 & $\begin{array}{l}\text { Carry out the preparation of plans, evaluation of programs and } \\
\text { budgets as well as reporting for the publication of research results }\end{array}$ \\
\hline
\end{tabular}

\begin{tabular}{|c|c|c|c|}
\hline & & - & $\begin{array}{l}\text { budgets as well as reporting for the publication of research results } \\
\text { and community service }\end{array}$ \\
\hline & & 12.4 & $\begin{array}{l}\text { Carry out the preparation of plans, evaluation of programs and } \\
\text { budgets as well as reporting in the development of the study center }\end{array}$ \\
\hline 13 & library & 13.1 & $\begin{array}{l}\text { Carrying out services, coaching, and developing libraries, holding } \\
\text { collaborations between libraries, controlling, evaluating, and } \\
\text { compiling library reports }\end{array}$ \\
\hline 14 & PTIPD & 14.1 & $\begin{array}{l}\text { Manage and develop management information systems, } \\
\text { development, network and application maintenance, database } \\
\text { management, other technology development and network } \\
\text { collaboration }\end{array}$ \\
\hline 15 & $\begin{array}{l}\text { Language } \\
\text { Center }\end{array}$ & 15.1 & $\begin{array}{l}\text { Carry out language training and development for the university's } \\
\text { academic community }\end{array}$ \\
\hline 16 & P2B & 16.1 & $\begin{array}{l}\text { Carry out management, marketing, and business development of the } \\
\text { university }\end{array}$ \\
\hline 17 & $\begin{array}{l}\text { Internatio } \\
\text { nal affairs } \\
\text { office }\end{array}$ & 17.1 & Carry out the management of International Services \\
\hline 18 & $\begin{array}{l}\text { Ma'had al- } \\
\text { Jamiah }\end{array}$ & 18.1 & $\begin{array}{l}\text { Carrying out services, coaching, academic development and student } \\
\text { character based on Islamic boarding schools }\end{array}$ \\
\hline 19 & $\begin{array}{l}\text { UIN Press } \\
\text { Printing }\end{array}$ & 19.1 & Carry out publishing and management in the printing sector \\
\hline 20 & SPI & 20.1 & Implementing Internal Control \\
\hline
\end{tabular}




\subsection{System Architecture}

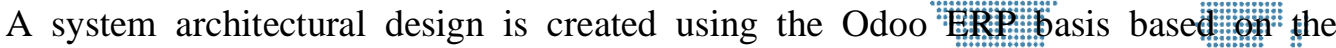
outcomes of the business process identification, as shown below.

Table 2. Procedures for AAK Mutation "...

\begin{tabular}{|c|c|c|c|c|c|c|c|c|c|c|c|c|}
\hline \multirow[b]{2}{*}{ No. } & \multirow[b]{2}{*}{ Activity } & \multicolumn{7}{|l|}{ Executor } & \multicolumn{3}{|c|}{ Raw Quality } & \multirow[b]{2}{*}{ Ket } \\
\hline & & Student & $\begin{array}{l}\text { General } \\
\text { Affair }\end{array}$ & $\begin{array}{l}\text { AUPK } \\
\text { Bureau }\end{array}$ & $\begin{array}{l}\text { Head of } \\
\text { AAKK }\end{array}$ & $\begin{array}{l}\text { Head of } \\
\text { Academic }\end{array}$ & $\begin{array}{c}\text { Head of } \\
\text { Subdivision } \\
\text { for Academic } \\
\text { Adm }\end{array}$ & $\begin{array}{c}\text { Head of Sub } \\
\text { Division } \\
\text { Adm. And } \\
\text { Academic } \\
\text { Information }\end{array}$ & Completeness & Time & Output & \\
\hline 1 & $\begin{array}{l}\text { Submit a mutation } \\
\text { application addressed to } \\
\text { the Chancellor (included in } \\
\text { the General Section) }\end{array}$ & & & & & & & & $\begin{array}{l}\text { The application is } \\
\text { accompanied by } \\
\text { the terms of } \\
\text { approval from the } \\
\text { department, good } \\
\text { behavior from the }\end{array}$ & 15 minutes & $\begin{array}{l}\text { Application } \\
\text { letter and } \\
\text { transfer } \\
\text { requirements } \\
\text { fle }\end{array}$ & \\
\hline 2 & $\begin{array}{l}\text { The Head of the AUPK } \\
\text { Bureau shall assign the } \\
\text { application letter to the Head } \\
\text { of the AAKK }\end{array}$ & & & & & & & & Disposition sheet & 30 minutes & \begin{tabular}{|l|} 
AUPK Head of \\
Disposition \\
Sheet
\end{tabular} & \\
\hline 3 & $\begin{array}{l}\text { The AAKK Head of Bureau } \\
\text { assigns to the AK Division } \\
\text { Head }\end{array}$ & & & & & & & & Disposition sheet & 60 minutes & $\begin{array}{l}\text { AAKK Head of } \\
\text { Disposition } \\
\text { Sheet }\end{array}$ & \\
\hline 4 & $\begin{array}{l}\text { The AK Division Head gives } \\
\text { instructions to the AK Sub } \\
\text { Division Head to make a } \\
\text { mutation letter }\end{array}$ & & & & & t & & & $\begin{array}{l}\text { AAKK Head of } \\
\text { Disposition } \\
\text { Sheet }\end{array}$ & 60 minutes & & \\
\hline 5 & $\begin{array}{l}\text { The AK Subdivision Head } \\
\text { makes a transfer letter }\end{array}$ & & & & & & & & & 10 minutes & $\begin{array}{l}\text { Transfer letter } \\
\text { draft }\end{array}$ & \\
\hline 6 & $\begin{array}{l}\text { The Head of Subdivision of } \\
\text { Adm and Information } \\
\text { processes the granting of a } \\
\text { new NIM }\end{array}$ & & & & & & & & $\begin{array}{l}\text { Transfer letter } \\
\text { draft }\end{array}$ & 5 minutes & New ID & \\
\hline 7 & Give initial & & & & & & & & $\begin{array}{l}\text { The draft of the } \\
\text { transfer letter that } \\
\text { has been given a } \\
\text { new NIM }\end{array}$ & 10 minutes & $\begin{array}{l}\text { The most } \\
\text { recent transfer } \\
\text { letter }\end{array}$ & \\
\hline 8 & $\begin{array}{l}\text { Signing the mutation } \\
\text { statement }\end{array}$ & & & & & & & & $\begin{array}{l}\text { The most recent } \\
\text { transfer letter }\end{array}$ & 5 minutes & $\begin{array}{l}\text { Confirmed } \\
\text { letter }\end{array}$ & \\
\hline 9 & $\begin{array}{l}\text { Students receive a transfer } \\
\text { approval letter with a new } \\
\text { NIM }\end{array}$ & & & & & & & & Confirmed letter & 5 minutes & $\begin{array}{l}\text { Accepted by } \\
\text { students }\end{array}$ & \\
\hline 10 & 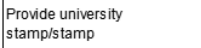 & & & & & & & & & & $\begin{array}{l}\text { Stamped } \\
\text { university }\end{array}$ & \\
\hline
\end{tabular}

Table 3. AUPK for RM Salary Submission

\begin{tabular}{|c|c|c|c|c|c|c|c|c|c|c|c|}
\hline \multirow{2}{*}{ No. } & \multirow{2}{*}{ Activity } & \multicolumn{6}{|c|}{ Executor } & \multicolumn{3}{|c|}{ Raw Quality } & \multirow{2}{*}{ Ket } \\
\hline & & BP & KDP & PPSPM & KPA & KPPN & Bank & Completeness & Time & Output & \\
\hline 1 & \begin{tabular}{|l|} 
PPABP prepares the \\
completeness of the Salary List \\
to make a detailed list of \\
requests by inputting and \\
printing from the GPP \\
Application to be submitted to \\
the PPK
\end{tabular} & & & & & & & $\begin{array}{l}\text { POK RKA } \\
\text { KLIDIPA }\end{array}$ & 1 day & $\begin{array}{l}\text { LS SPP } \\
\text { Completenes } \\
\text { s Draft }\end{array}$ & \\
\hline 2 & $\begin{array}{l}\text { PPABP examines the } \\
\text { completeness and submits it to } \\
\text { PPK for signature, then SPP is } \\
\text { issued }\end{array}$ & & & & & & & $\begin{array}{l}\text { LS SPP } \\
\text { Completeness } \\
\text { Draft }\end{array}$ & $\begin{array}{l}10-30 \\
\text { minutes }\end{array}$ & $\begin{array}{l}\text { SPP signed } \\
\text { by PPK }\end{array}$ & \\
\hline 3 & $\begin{array}{l}\text { The LS SPP file is requested for } \\
\text { approval from the KPA }\end{array}$ & & & & & & & $\begin{array}{l}\text { SPP signed by } \\
\text { PPK }\end{array}$ & 10 minutes & $\begin{array}{l}\text { KPA } \\
\text { approved } \\
\text { tuition fees }\end{array}$ & \\
\hline 4 & $\begin{array}{l}\text { Atter KPA approves then } \\
\text { PPSPM examines/verifies the } \\
\text { completeness of the SPP to } \\
\text { then issue the SPM. }\end{array}$ & & & & & & & $\begin{array}{l}\text { KPA approved } \\
\text { tuition fees }\end{array}$ & 15 minutes & SPM & \\
\hline 5 & $\begin{array}{l}\text { Furthermore, the Print SPM \& } \\
\text { ADK SPM along with the } \\
\text { completeness are submitted to } \\
\text { KPPN }\end{array}$ & & & & & & & $\begin{array}{l}\text { SPM and } \\
\text { accessories }\end{array}$ & $1-3$ hours & SPM & \\
\hline 6 & 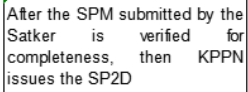 & & & & & & & SPM & 1 day & SP2D & \\
\hline 7 & $\begin{array}{l}\text { Employee salaries are credited } \\
\text { to their respective accounts }\end{array}$ & & & & & & $\downarrow$ & SPM & 1 day & SP2D & \\
\hline 8 & \begin{tabular}{|l|} 
Treasurer records SP2D Salary \\
Then in the General Cash Book \\
and Assistance Book consisting \\
of. Tax Assistance Book, Cash \\
Cash Assistance Book, Bank \\
Assistance Book, and Credit \\
Supervision Assistance Book
\end{tabular} & & & & & & & SP2D & $\begin{array}{l}15-30 \\
\text { minutes }\end{array}$ & Bookkeeping & \\
\hline
\end{tabular}


Table 4. Issuance of Documented Information by the ISO Secretariat Gentrol

\section{Document}

\begin{tabular}{|c|c|c|c|c|c|c|c|}
\hline \multirow[b]{2}{*}{ No. } & \multirow[b]{2}{*}{ Activity } & \multicolumn{2}{|c|}{ Executor } & \multicolumn{3}{|c|}{ Raw Quality } & \multirow[b]{2}{*}{ Ket } \\
\hline & & ISO Secretariat & $\begin{array}{c}\text { Authorized } \\
\text { Officer }\end{array}$ & Completeness & Time & Output & \\
\hline 1 & \begin{tabular}{|l|} 
The processes that exist in the scope of application of the \\
quality management system at UIN Maulana Malik Ibrahim are \\
informed and documented in a documented information \\
(document) quality system
\end{tabular} & & & $\begin{array}{l}\text { Quality system } \\
\text { Documented } \\
\text { Information } \\
\text { (Documents) }\end{array}$ & 1 week & $\begin{array}{l}\text { Quality system } \\
\text { document } \\
\text { results }\end{array}$ & \\
\hline 2 & $\begin{array}{l}\text { Quality system documents are checked and approved by } \\
\text { authorized officials in accordance with the Authorized Table of } \\
\text { Authorization Documented information (documents) attached }\end{array}$ & & & \begin{tabular}{|l|} 
Documented \\
Information \\
(Documents) quality \\
system $\cdot$ Authority \\
to validate \\
Documented \\
Information \\
(Documents)
\end{tabular} & 1 day & $\begin{array}{l}\text { Certified quality } \\
\text { system } \\
\text { document }\end{array}$ & \\
\hline 3 & $\begin{array}{l}\text { Documented information (document) of the quality system that } \\
\text { has been approved, stamped "MORE" on the approval sheet, and } \\
\text { recorded in the Register of Documented Information (document) } \\
\text { of the Master. This documented information (document) is stored } \\
\text { in the ISO Secretariat }\end{array}$ & & & $\begin{array}{l}- \text { Quality system } \\
\text { documents } \cdot \\
\text { Stamps } \cdot \text { Attestation } \\
\text { sheets } \cdot \text { Master } \\
\text { documents }\end{array}$ & 1 day & $\begin{array}{l}\text { Documented } \\
\text { Information } \\
\text { (Document) } \\
\text { Master }\end{array}$ & \\
\hline 4 & $\begin{array}{l}\text { Documented information (external document) that is used as a } \\
\text { reference in carrying out work at UIN Maulana Malik Ibrahim is } \\
\text { stamped "REFERENCE USED" and recorded in the List of } \\
\text { Documented Information (External Document). }\end{array}$ & & & $\begin{array}{l}\text { External } \\
\text { Documented } \\
\text { Information } \\
\text { (Documents) }\end{array}$ & 1 day & \begin{tabular}{|l} 
List of External \\
Documented \\
Information \\
(Documents)
\end{tabular} & \\
\hline
\end{tabular}

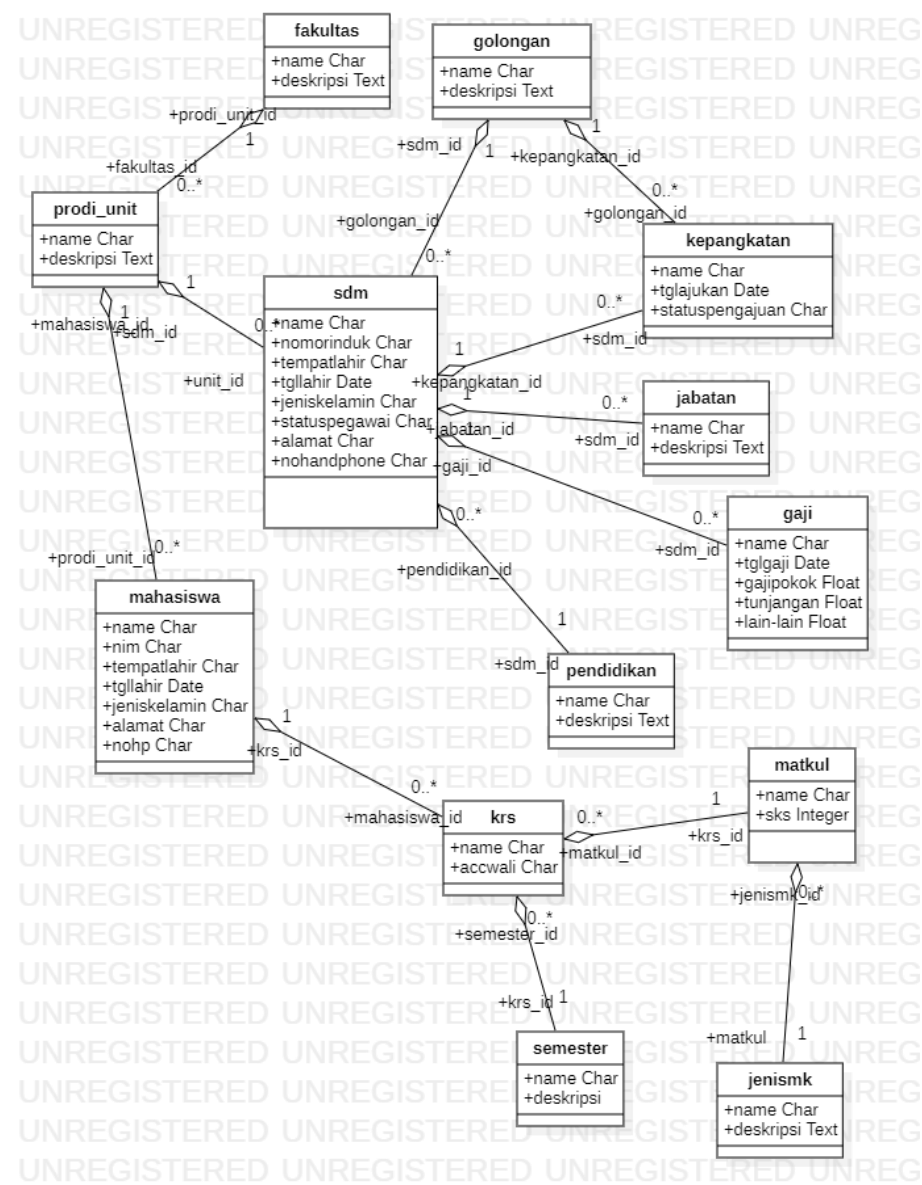

Figure 1. System Architecture

The Odoo ERP platform can be used to generate this design, as shown in the following image. 


\section{Csinta ${ }^{(4)}$}

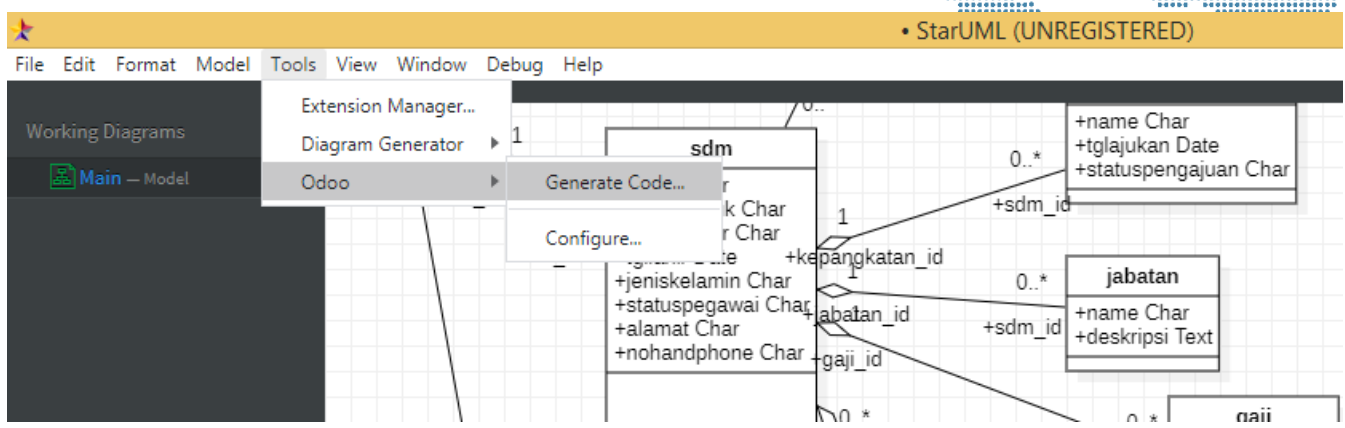

Figure 2. Generate System Architecture

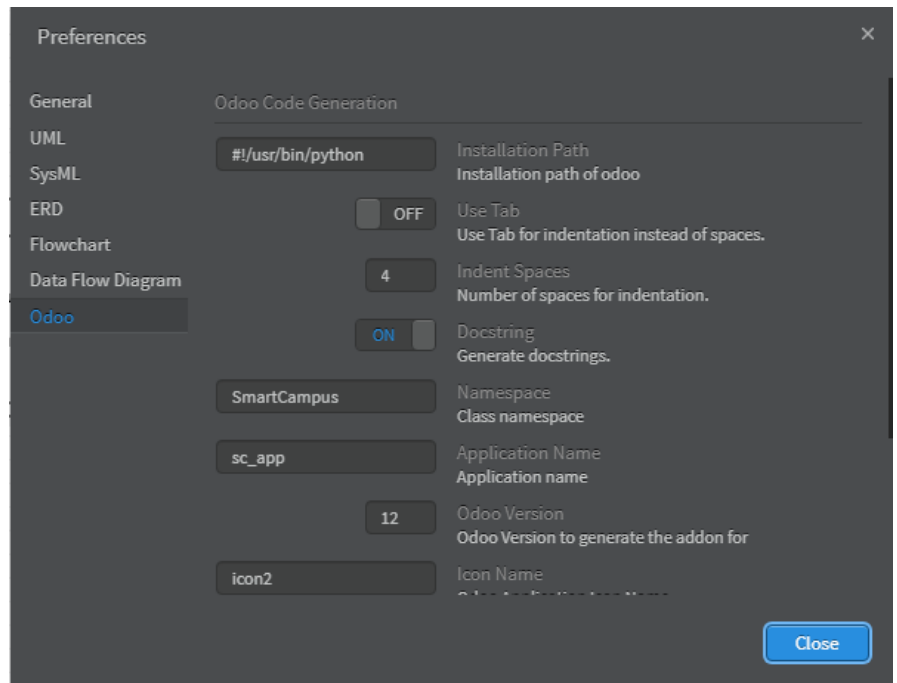

Figure 3. System Architecture Configuration Using Odoo ERP Platform

\section{Conclusion}

Using the odoo ERP platform, the following research resulted in the identification of business processes in each sub-satker and system architecture modeling. The results of the architectural design show that the methods used are compatible with the existing problems, allowing them to produce designs and implement the subsatker section at UIN Maulana Malik Ibrahim Malang. The system architectural design utilizing the Star UML tool with the addition of Odoo ERP addons generates a suitable design because in its development it has adopted the notion of Enterprise Resource Planning.

\section{References}

[1] M. S. Mustaqbal, R. F. Firdaus, and H. Rahmadi, "Pengujian Aplikasi Menggunakan Black Box Testing Boundary Value Analysis (Studi Kasus: Aplikasi Prediksi Kelulusan SNMPTN)," vol. I, no. 3, pp. 31-36, 2015.

[2] A. Puspita Sari and A. Setiawan, "The Development of Internet-Based Economic Learning Media using Moodle Approach," Int. J. Act. Learn., vol. 3, no. 2, pp. 100-109, 2018, [Online]. Available: http://journal.unnes.ac.id/nju/index.php/ijal.

[3] S. M. Huang, W. C. Shen, D. C. Yen, and L. Y. Chou, "IT governance: Objectives and assurances in internet banking," Adv. Account., vol. 27, no. 2, pp. 406-414, 2011, doi: 10.1016/j.adiac.2011.08.001.

[4] J. Ha, "A Study on the Development and Effectiveness of a Teaching-Learning Model Based on Flipped Learning and PBL," J. Probl. Learn., vol. 5, no. 1, pp. 45-54, 2018, doi: 10.24313/jpbl.2018.5.1.45.

[5] A. Bachtiar and U. Hasanah, "Perencanaan Strategis SI/TI Pada Perguruan Tinggi (Studi Kasus: STMIK Bumigora Mataram),” J. Matrik, vol. 16, no. 2, p. 45, 2017, 
doi: 10.30812/matrik.v16i2.2.

[6] S. H. Almugadam, B. I. Bashir, A. A. A. Hassan, and M. A. A, "Developing tool for Odoo platform," Proc. - 2017 Int. Cornf. Commun. centrol. Comput. Electron. Eng. ICCCCEE 201\%, 2017, doi: 10.1109/ICCCCEE.2017.7867677.

[7] T. Semiawan and M. Middleton, "Strategic information planning and campus information systems development in Indonesia," Campus-Wide Inf. Syst., vol. 16, no. 2, pp. 70-76, Jan. 1999, doi: 10.1108/10650749910272025.

[8] F. R. Shamekh, "Business-IT Strategic Alignment Concept in Theory and Practice," IT Univ. GOTEBORG, pp. 1-66, 2008, [Online]. Available: https://gupea.ub.gu.se/handle/2077/10496\%5Cnhttp://scholar.google.com/scholar? $\mathrm{hl}=$ en\&btnG=Search\&q=intitle:Business-

IT+Strategic+Alignment+Concept+in+Theory+and+Practice\#0.

[9] M. R. Vitale, B. Ives, and C. M. Beath, "Linking information technology and corporate strategy: an organizational view," Proc. Seventh Int. Conf. Inf. Syst., vol. 15, p. $17,1986$.

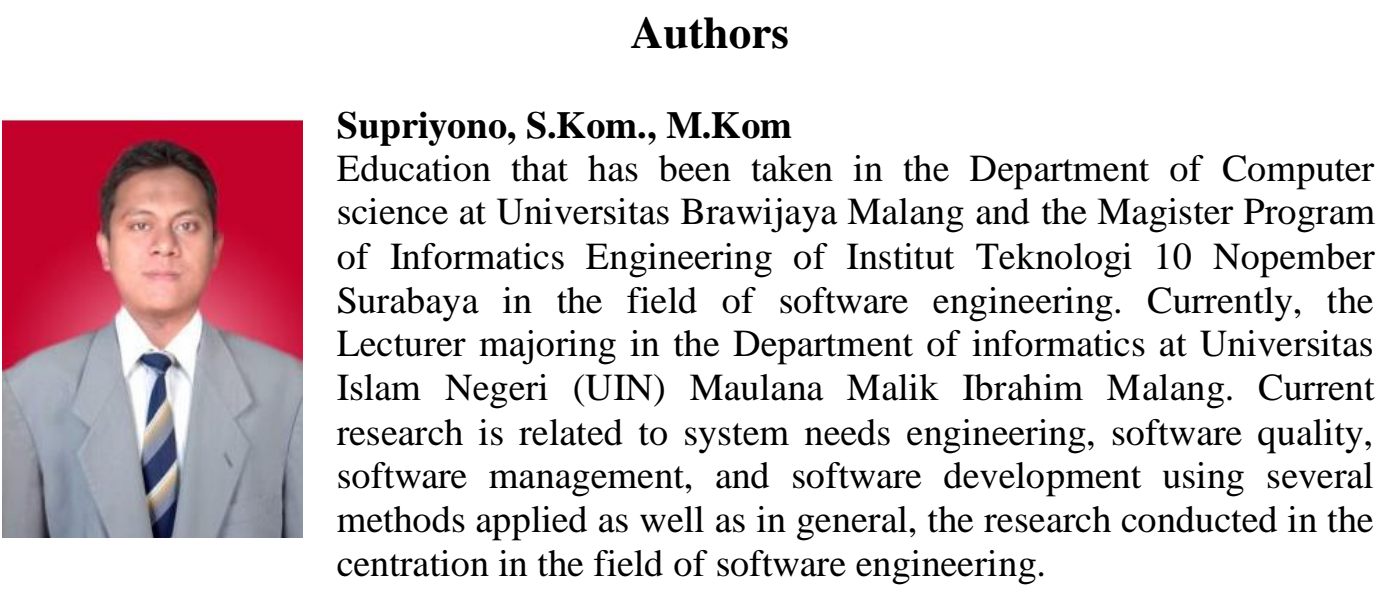

